\title{
Genetic Analysis of Fusion Recombinants and Presence of Noncomplementing Diploids in Bacillus megaterium
}

\author{
By EDWIN R. FLEISCHER† AND PATRICIA S. VARY* \\ Department of Biological Sciences, Northern Illinois University, DeKalb, Illinois 60115, USA
}

(Received 10 July 1984; revised 13 November 1984)

\begin{abstract}
We have attempted to undertake genetic analysis in Bacillus megaterium using the technique of protoplast fusion that has been successfully applied in Staphylococcus and Streptomyces. Efficient production of protoplasts, fusion and regeneration techniques have been established. However, variability in numbers and types of recombinants using two-, three-, and four-factor crosses was observed throughout these studies. No linkages were detected, even between loci known to be linked by cotransduction with bacteriophage MP13. These results were similar to those reported by Alföldi and coworkers using B. megaterium strain 216, even though the experimental design was significantly changed. During initial subculturing, segregants were observed in a $1: 2: 2$ ratio of noncomplementing diploids:parental-1:parental-2. The ratio changed dramatically after seven subcultures. Double recombinants appeared after nine subcultures. These results corroborate those reported in $B$. subtilis and suggest that there is a locus-inactivation phenomenon present in Bacillus which is not evident in Streptomyces or Staphylococcus. Until the mechanism is elucidated, protoplast fusion should not be used for chromosomal mapping in $B$. megaterium. However, it can be used to transfer plasmids among the bacilli at a frequency of $10^{-5}-10^{-6}$ per regenerated protoplast.
\end{abstract}

\section{INTRODUCTION}

Polyethylene glycol-mediated fusion of bacterial protoplasts was first reported in the genus Bacillus. Bacillus subtilis (Schaeffer et al., 1976) and Bacillus megaterium (Fodor \& Alföldi, 1976) were both shown to produce recombinants when multiply auxotrophic parental cells were stripped of their cell walls, then fused in the presence of polyethylene glycol. Recombinants exhibiting all possible combinations of parental markers could be recovered following regeneration of bacillary forms on hypertonic media. Both electron-microscopic analysis and phage complementation studies further demonstrated that fusion occurs by a two-step process involving multiple cell fusions (Frehel et al., 1979; Sanchez-Rivas \& Garro, 1979). Unfortunately, variability in the recombination frequencies was soon reported in both species (Hotchkiss \& Gabor, 1980; Fodor \& Alföldi, 1979), and the latter investigators observed that in $B$. megaterium the physiological state of the cells prior to protoplast formation seemed greatly to influence the number and types of recombinants recovered. Sanchez-Rivas et al. (1982) demonstrated that in $B$. subtilis up to $50 \%$ of prototrophs recovered after fusion were unstable complementing diploids. In addition to the unstable prototrophs, they observed a small percentage of unstable noncomplementing diploids (Ncds), also called biparentals, in which one or the other chromosome in a diploid fusion product is inactivated. The silent chromosome remains unexpressed until segregation occurs (Hotchkiss \& Gabor, 1980; Sanchez-Rivas et al., 1982). To try to understand what was different about the two chromosomes in a Ncd cell, Guillen et al. (1982) gently isolated the nucleoids from Ncd colonies and observed a difference in

$\uparrow$ Present address: Molecular Genetics Inc., Minnetonka, MN, USA.

Abbreviation: Ncd, noncomplementing diploid. 
density between expressed and unexpressed chromosomes after centrifugation through $\mathrm{CsCl}$ gradients. They concluded from the density shift that a change in the tertiary structure of the inactivated chromosome, rather than a difference in methylation, caused it to be faster sedimenting. The unexpressed chromosome was also shown to have much reduced transforming ability (Bohin et al., 1982). However, the transforming ability of the inactivated loci could be increased 20- to 50-fold by treatment of the DNA with proteases prior to transformation, implying that a protein bound to the DNA was preventing gene expression. Guillen et al. (1983) have further shown, by following $\phi 105$ induction in silent and expressed Ncd chromosomes, that no transcription of repressor mRNA occurs when the phage is carried on the silent chromosome.

Protoplast fusion is potentially a powerful genetic tool. It has now been successfully used for genetic mapping in Streptomyces (Baltz, 1978; Hopwood \& Wright, 1978; Hopwood et al., 1979) and in Staphylococcus (Stahl \& Pattee, 1983). It might be possible to establish conditions for genetic analysis by protoplast fusion in Bacillus if the correct conditions could be found. Indeed, Dancer \& Mandelstam (1981) fused B. subtilis strains in experiments which enabled them to observe complementation patterns among several spo mutants.

Our laboratory has been undertaking genetic mapping in $B$. megaterium for approximately five years using a generalized transducing phage MP13 (Vary, 1979; Vary et al., 1982; Callahan et al., 1983; Garbe et al., 1984). We are also interested in developing other methods of genetic analysis to augment our transductional studies and decided to try protoplast fusion as a possible method for ordering mutations on the $B$. megaterium chromosome. Ncds had not been reported in $B$. megaterium, and Hopwood (1981) suggested that some of the variability in recombinants observed by Fodor \& Alföldi (1979) in B. megaterium might have been because of their use of selective regeneration media. Therefore, we tried to undertake genetic mapping in $B$. megaterium by protoplast fusion using non-selective regeneration media. This paper reports that the difficulties in recombinant variability encountered in both $B$. megaterium and $B$. subtilis are not solved by the use of a non-selective regeneration medium, and that Ncd clones are also produced in $B$. megaterium. These Ncd clones show similar segregation patterns to those observed in $\mathrm{Ncd}$ clones arising from protoplast fusion in $B$. subtilis.

\section{METHODS}

Strains and culture conditions. The strains used in this study were derived from Bacillus megaterium QM B1551 (ATCC 12778) or from B. subtilis 168 and are shown in Table 1. Routine culturing was done as reported previously (Garbe et al., 1984) using supplemented nutrient broth (SNB; Shay \& Vary, 1978) with selection for prototrophic markers on minimal glucose medium (MC; Lammi \& Vary, 1972). Regeneration media included; DM3 (Chang \& Cohen, 1979$), 10 \%$ (w/v) sucrose nutrient agar (10\% SNA; B. C. Carlton, personal communication), R medium (Schaeffer et al., 1976), and minimal hypertonic medium (HGM; Fodor et al., 1975). Sucrose/magnesium/maleate buffer (SMM; Wyrick \& Rogers, 1973), was used for protoplast formation and stabilization, and SMMP (equal volumes of $2 \times$ SMM and $4 \times$ Penassay broth; Chang \& Cohen, 1979) was used both to dilute PEG-treated cells and as a post-PEG incubation medium. PEG solution (40\%,w/v; mol. wt 8000 ; Sigma) contained $40 \%$ (w/v) PEG in $2 \times$ SMM.

Protoplast fusion. Several published methods were tested and modified to improve fusion in our species. The highest yield of recombinants was found using the method of Gabor \& Hotchkiss (1979) with mid-exponential phase cells $\left(\mathrm{OD}_{660} 0.5\right.$, measured in a Perkin-Elmer $\lambda 3$ spectrophotometer, equivalent to $2 \times 10^{7}$ c.f.u. $\left.\mathrm{ml}^{-1}\right)$ and $40 \%(\mathrm{w} / \mathrm{v})$ PEG. Unless otherwise indicated, $100 \mathrm{ml}$ of each parental culture was grown in SNB to $\mathrm{OD}_{660} 0.5$, and the cells were pelleted at $5000 \mathrm{~g}$ at room temperature, resuspended in $0.1 \mathrm{vol}$. SMMP with $250 \mu \mathrm{g}$ lysozyme $\mathrm{ml}^{-1}$ and gently shaken for $30 \mathrm{~min}$ at $30^{\circ} \mathrm{C}$. The protoplasts were washed twice with, and then resuspended in $1 \mathrm{ml}$ of, SMMP. Equal amounts $(0.1 \mathrm{ml})$ of each parental strain were mixed, and $0.8 \mathrm{ml} 40 \%(\mathrm{w} / \mathrm{v})$ PEG was added; after $2 \mathrm{~min}$ incubation the protoplasts were diluted with $5 \mathrm{ml} \mathrm{SMMP,} \mathrm{pelleted} \mathrm{by} \mathrm{centrifugation} \mathrm{at} 2600 \mathrm{~g}$ for $5 \mathrm{~min}$, resuspended in $1 \mathrm{ml}$ SMM, diluted $10^{6}$-fold and plated on regeneration medium. Controls included in each protocol were: (1) parental protoplasts without PEG treatment, and (2) a parallel culture of unprotoplasted parental cells treated with PEG. After incubation for $24-36 \mathrm{~h}$, well-separated colonies $(<100$ per plate) were picked at random to master plates of minimal medium complete with all required amino acids. These master plates were replicated after $16-24 \mathrm{~h}$ incubation at $30^{\circ} \mathrm{C}$ to appropriate selective media and were scored after $24 \mathrm{~h}$. Colonies that showed growth on each parental medium and on complete medium, but did not grow on minimal medium, were designated as Ncds (Guillen et al., 1982). 
Table 1. Bacterial strains

\begin{tabular}{llr}
\multicolumn{1}{c}{ Organism* } & \multicolumn{1}{c}{ Genotype } & Source/Re \\
Bacillus megaterium & & \multicolumn{1}{c}{ prototrophic } \\
QM B1551 & pheA20 & 2 \\
PV30 & argO25 & 6 \\
PV33 & leuC4 trp-27 str-3 \\
PV57 & gly-21 & 6 \\
PV59 & cys-20 erm-3 & 6 \\
PV104 & ilv-4 thr-22 str-3 \\
PV143 & ilv-4 leuA25 str-3 & 6 \\
PV160 & cys-20 erm3 & 6 \\
PV170/pCM194 $\left(\mathrm{Cm}^{\mathrm{R}}\right)$ & 2 \\
JV26 & str-1 & 3 \\
JV78 & leuC4 str-3 & 1 \\
Bacillus subtilis & & 4 \\
BR151/pCM194 $\left(\mathrm{Cm}^{\mathrm{R}}\right)$ & trpC2 lys-3 metB10 \\
BR151/pUB110 $\left(\mathrm{Km}^{\mathrm{R}}\right)$ & trpC2 lys-3 metB10 \\
Staphylococcus aureus & & 4 \\
1SP479/p1258 $\left(\mathrm{Em}^{\mathrm{R}}\right)$ & pig-131/bla-401 mer-14 repA36 & 5 \\
& Tn551 (ermB $)$ &
\end{tabular}

\footnotetext{
* Strains with a PV prefix originated in this laboratory. Strains with a JV prefix are from the laboratory of J. C. Vary. All B. megaterium strains are derived from QM B1551.

† 1, Vary (1972); 2, Garbe et al. (1984); 3, J. C. Vary, University of Illinois, Chicago, USA; 4, P. Lovett, University of Maryland, Catonsville, USA; 5, P. Pattee, lowa State University, Ames, lowa, USA; Luchansky \& Pattee (1984); 6, this study.
}

Subcloning Ncd colonies. Colonies classified as Ncd were picked with sterile toothpicks from different media, inoculated separately into $S N B$, shaken at $30^{\circ} \mathrm{C}$ until they reached an $O_{660}$ of $0.4-0.8$, and then were streaked on SNB agar or minimal medium with appropriate supplements. After $16-24 \mathrm{~h}$ at $30^{\circ} \mathrm{C}$, well-isolated single colonies were transferred with toothpicks to master grids on the same medium. After a further $16-24 \mathrm{~h}$ growth at $30^{\circ} \mathrm{C}$, the master grids were replica plated to selective media and the colonies were reclassified as parental, recombinant, or Ncd.

Transfer of plasmids by fusion. Cultures of the desired plasmid-bearing Bacillus strain and plasmid-less strain were grown in Penassay broth (Difco) with all requirements and fused according to Dancer (1980). After diluting the PEG-treated protoplasts in $5 \mathrm{ml} \mathrm{SMMP}$ and centrifuging at $2500 \mathrm{~g}$ at room temperature, the pellet was gently resuspended in $1 \mathrm{ml}$ SMMP and given $4 \mathrm{~h}$ post-PEG incubation at $30^{\circ} \mathrm{C}$ to allow for phenotypic expression. Samples were then removed, diluted $10^{6}$-fold, and plated on DM3 regeneration medium supplemented with the appropriate selective antibiotics. The plates were incubated for $48 \mathrm{~h}$ at $30^{\circ} \mathrm{C}$ for $B$. megaterium, or $37^{\circ} \mathrm{C}$ for $B$. subtilis, then scored for antibiotic resistance. The frequency of plasmid transfer was calculated by dividing the number of resistant colonies per $\mathrm{ml}$ by the number of colonies per $\mathrm{ml}$ that were obtained in the absence of selection.

Plasmid isolation and agarose gel electrophoresis. Plasmids were isolated by the rapid method of Birnboim \& Doly (1979) and analysed by electrophoresis through $.0 .7 \%$ agarose as previously described (Kieselburg et al., 1984).

Chemicals and reagents. PEG, chloramphenicol, streptomycin, lincomycin, kanamycin, erythromycin, lysozyme and BSA were obtained from Sigma. Cadmium nitrate was purchased from Mallinckrodt Chemical Works (St Louis, MO., USA), SDS from Eastman Kodak and agarose from Bio-Rad. All other chemicals were of reagent grade.

\section{RESULTS}

Determination of optimum conditions for protoplast production and regeneration of bacillary forms

Starting with the procedure of Gabor \& Hotchkiss (1979), several conditions, including phase of growth, lysozyme concentration, $\mathrm{pH}$ and temperature, were varied to establish the most efficient method of producing protoplasts. Efficiency of protoplasting $(A)$ was calculated as $A=$ $1-a / b$ (equation 1 ), where $a$ is the colony count following osmotic shock of protoplasts in water, and $b$ is the colony count of the unprotoplasted culture. When each condition was varied separately, the highest efficiencies of protoplasting were obtained with cells grown to $\mathrm{OD}_{660} 0.5$ $(99.2 \%)$, lysed in $250 \mu \mathrm{g}$ lysozyme $\mathrm{ml}^{-1}$ in SMM (99.3\%) at pH 6.5 (96.2\%) for $30 \mathrm{~min}(99.1 \%)$ at $32{ }^{\circ} \mathrm{C}(99 \cdot 3 \%)$. These conditions were combined and used in all subsequent fusions. 
Table 2. Results of fusion of B. megaterium strains of PV57 (trp-27 leuC4 str-3) and PV143 (ilv-4 thr-22 str-3)

Fusion of protoplasts was done using optimum conditions. Parental cultures (about $2 \times 10^{7}$ c.f.u. $\mathrm{ml}^{-1}$ ) were converted to protoplasts and fused as described in Methods. The mixture was diluted and plated for single colonies on nonselective regeneration media. After $36 \mathrm{~h}$ incubation, colonies were replica plated to all necessary media to test for phenotype. Conditions in all three experiments were identical.

\begin{tabular}{|c|c|c|c|c|c|c|c|}
\hline \multicolumn{5}{|c|}{ Phenotype* } & \multicolumn{3}{|c|}{ No. of colonies $\dagger$} \\
\hline Trp & Leu & Ilv & Thr & & Expt 1 & Expt 2 & Expt 3 \\
\hline 1 & 1 & 1 & 1 & Trp- Leu$^{-}$(parental) & 479 & 491 & 500 \\
\hline 0 & 0 & 0 & 0 & Ilv $^{-} \mathrm{Thr}^{-}$(parental) & 622 & 376 & 321 \\
\hline 1 & 0 & 1 & 1 & $\operatorname{Trp}^{-}$ & 0 & $4(3 \cdot 0)$ & $22(12.4)$ \\
\hline 0 & 1 & 1 & 1 & $\mathrm{Leu}^{-}$ & $16(4 \cdot 0)$ & $13(9 \cdot 8)$ & $5(2 \cdot 8)$ \\
\hline 0 & 0 & 0 & 1 & $\mathrm{Ilv}^{-}$ & $79(19 \cdot 8)$ & $3(2 \cdot 2)$ & $39(22 \cdot 0)$ \\
\hline 0 & 0 & 1 & 0 & $\mathrm{Thr}^{-}$ & $29(7 \cdot 3)$ & $5(3 \cdot 8)$ & $17(9 \cdot 6)$ \\
\hline 1 & 0 & 0 & 1 & Trp$^{-} \mathrm{Ilv}^{-}$ & $63(15 \cdot 8)$ & $16(12 \cdot 0)$ & $23(13.0)$ \\
\hline 1 & 0 & 1 & 0 & Trp $^{-}$Thr $^{-}$ & $68(17 \cdot 0)$ & $25(18 \cdot 8)$ & $6(3.4)$ \\
\hline 0 & 1 & 0 & 1 & Leu- $^{-} \mathrm{Ilv}^{-}$ & $76(19 \cdot 0)$ & $17(12 \cdot 8)$ & $16(9 \cdot 0)$ \\
\hline 0 & 1 & 1 & 0 & $\mathrm{Leu}^{-} \mathrm{Thr}^{-}$ & $20(5 \cdot 0)$ & $3(2 \cdot 3)$ & $14(7.9)$ \\
\hline 1 & 1 & 0 & 1 & Trp $^{-}$Leu- Ilv $^{-}$ & $7(1 \cdot 8)$ & $5(3.8)$ & $1(0.6)$ \\
\hline 1 & 1 & 1 & 0 & Trp- Leu $^{-}$Thr $^{-}$ & $1(0 \cdot 3)$ & $3(2 \cdot 3)$ & 0 \\
\hline 0 & 1 & 0 & 0 & Leu $^{-} \mathrm{Ilv}^{-} \mathrm{Thr}^{-}$ & $13(3 \cdot 3)$ & $8(6 \cdot 0)$ & $2(1 \cdot 1)$ \\
\hline 1 & 0 & 0 & 0 & Trp- Ilv- Thr- & $12(3.0)$ & $2(1.5)$ & $6(3.4)$ \\
\hline 1 & 1 & 0 & 0 & Trp $^{-}$Leu $^{-}$Ilv $^{-}$Thr- $^{-}$ & $2(0 \cdot 6)$ & 0 & $6(3.4)$ \\
\hline \multirow[t]{3}{*}{0} & 0 & 1 & 1 & Prototrophic & $13(3 \cdot 3)$ & $29(21 \cdot 8)$ & $20(11 \cdot 3)$ \\
\hline & & & & Total recombinants & 339 & 133 & 177 \\
\hline & & & & $\begin{array}{l}\text { Total percentage } \\
\text { of recombination }\end{array}$ & $26 \cdot 6 \%$ & $13 \cdot 3 \%$ & $17 \cdot 9 \%$ \\
\hline
\end{tabular}

The regeneration of protoplasts was also tested on several hypertonic media including $8 \%$, $10 \%$ and $12 \%$ SNA \pm BSA, DM3, R and HGM (see Methods). Regeneration efficiencies were measured by diluting lysozyme treated cells in either water or hypertonic buffer, plating on hypertonic media, and comparing the two plate counts. The regeneration efficiency (RE) was given by $\mathrm{RE}=[(e-a) / b] \times 1 / A$, where $e$ is the colony count after dilution in hypertonic buffer and $A, a$ and $b$ are the same as in equation 1 . The $10 \%$ SNA, which is very simple to prepare (in contrast to DM3 and HGM) gave the highest regeneration efficiency $(98.2 \%)$ and was used for all subsequent tests.

\section{Analysis of recombinants arising from protoplast fusion}

Several two-, three-, and four-factor crosses were attempted, including a cross between $B$. megaterium strains PV160 and PV30 which involved three loci (ilv, leu and phe) that had been shown previously to be linked by cotransduction (Garbe et al., 1984). There was no detectable reduction in recombination between these linked markers as compared with the frequency of recombination between unlinked markers in the cross (data not shown). Therefore, more extensive four-factor crosses were attempted, including the cross shown in Table 2 . In this experiment, inheritance of the ilv and leu markers, which are about $50 \%$ cotransduced by phage MP13, was studied by fusing PV57 with PV143. Since no linkage was seen between ilv and leu, the experiment was repeated twice. The results varied widely between experiments; however, it is noteworthy that every possible recombinant type could be recovered.

The frequencies of recombination calculated from the data in Table 2 are shown in Table 3. No apparent linkages could be detected. In an attempt to determine whether the recombination events were reciprocal, the frequencies of occurrence of each crossover in experiment 1 were calculated separately in each direction. The results (Table 3 ) indicate inconsistency even within one experiment. For example, if one looks at the frequency of recombination between trp and leu in each direction, one finds reciprocity, since the two classes are present at almost equal 
Table 3. Frequencies of recombination and reciprocal crossover derived from fusion of $B$. megaterium strains PV57 and PV143

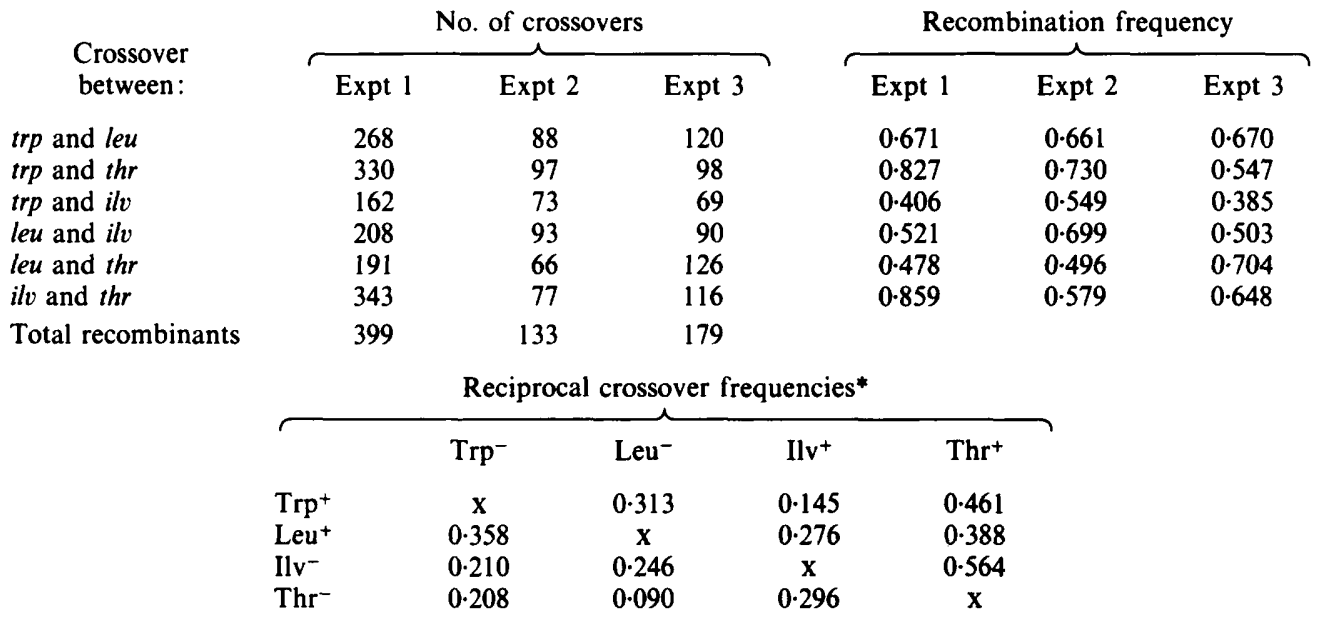

* Data from experiment 1. Frequencies of occurrence of reciprocal crossovers between two markers were determined by dividing the number of recombinants resulting from a crossover in each direction, e.g. $\operatorname{Trp}^{+} \mathrm{Leu}^{-} \mathrm{vs}$ Trp $^{-} \mathrm{Leu}^{+}$, by the total number of recombinants.

frequencies $(0.313$ and $0 \cdot 358)$. However, the frequencies of the recombinant classes arising from crossovers in the two directions between trp and $t h r$ and between leu and $t h r$ differ by more than two-fold and four-fold, respectively.

\section{Analysis of a Ncd colony}

Colonies that grew on both media selecting for either parental type, but that failed to grow on minimal medium, were detected at a frequency of $1-4 \%$ in almost every cross. One such Ncd colony resulting from a cross between $B$. megaterium strains PV33 (argO) and PV59 (gly-2l) (which grew when replicated to $\mathrm{MC}+$ glycine or $\mathrm{MC}+$ arginine but did not grow on $\mathrm{MC}$ ) was successively subcloned and analysed for the persistence of this trait (Table 4). A ratio of $1: 2: 2$ $\mathrm{Ncd}: \mathrm{Arg}^{-}: \mathrm{Gly}^{-}$was observed through six subclonings, after which the ratio became skewed toward recovery of $\mathrm{Arg}^{-}$and Ncd colonies. When all five Ncd colonies isolated from subcloning Ncd8 were each subcloned (Ncd9:1-5), it became clear that all five had shifted from the previous $1: 2: 2$ segregation pattern, since well over $50 \%$ of all the segregants were $\mathrm{Arg}^{-}$. Subclones Ncd $9: 3$ and Ncd $9: 5$ also yielded prototrophic segregants. Since Ncd $9: 3$ was the only one of the five which segregated out all four genotypes, it was subcloned again and 250 colonies were analysed. The rare $\mathrm{Arg}^{-} \mathrm{Gly}^{-}$recombinants were then detected (Table 4).

\section{Interspecies plasmid transfer}

Dancer (1980) reported interspecies transfer of plasmids by protoplast fusion. Therefore, $B$. subtilis strain BR151 $\left(\mathrm{Em}^{\mathrm{S}}\right)$ carrying either pCM194 $\left(\mathrm{Cm}^{\mathrm{R}}\right)$ or pUB110 $\left(\mathrm{Km}^{\mathrm{R}}\right)$ plasmids was fused with $B$. megaterium PV104 $\left(\mathrm{Em}^{\mathrm{R}}\right)$ in the presence of PEG and cells were regenerated on a medium containing both erythromycin and either chloramphenicol or kanamycin as appropriate. The $B$. megaterium colonies receiving the plasmids were verified by colonial and microscopic appearance, auxotrophic requirements and MP13 phage sensitivity. No evidence of chromosomal transfer was detected in the colonies receiving plasmids. Several inter- and intraspecies crosses are shown in Table 5 . The first cross was done before optimal conditions had been established, and so gave a low frequency of transfer. It is shown because it generated strain PV170, which was used as donor in subsequent tests. The presence of pCM194 in PV170 was verified by agarose gel electrophoresis. Repeated attempts to transfer pI258, a plasmid in Staphylococcus aureus strain 1SP479, failed even though fusion pairs between protoplasts of $B$. megaterium and $S$. aureus could be seen by phase-contrast microscopy. 
Table 4. Subcloning of a Ncd colony resulting from fusion of B. megaterium strains $P V 33(\arg O)$ and PV59 (gly-21)

\begin{tabular}{|c|c|c|c|c|c|}
\hline \multirow[b]{2}{*}{ Colony } & \multicolumn{5}{|c|}{ Phenotype ( $\%$ of total) } \\
\hline & Ncd & $\mathrm{Arg}^{-}$ & Gly $^{-}$ & $\mathrm{Arg}^{+} \mathrm{Gly}^{+}$ & $\mathrm{Arg}^{-} \mathrm{Gly}^{-}$ \\
\hline $\begin{array}{l}\text { Ncd1* } \\
\text { Ncd2 } \\
\text { Ncd3 } \\
\text { Ncd4 } \\
\text { Ncd5 } \\
\text { Ncd6 } \\
\text { Ned7 } \\
\text { Ned8 } \\
\text { Ned9 } \\
\text { Ned10 }\end{array}$ & $\begin{array}{l}22 \\
24 \\
20 \\
14 \\
26 \\
20 \\
53 \\
10 \\
58 \\
14\end{array}$ & $\begin{array}{l}38 \\
40 \\
46 \\
38 \\
32 \\
36 \\
44 \\
84 \\
28 \\
84\end{array}$ & $\begin{array}{r}40 \\
36 \\
34 \\
48 \\
42 \\
44 \\
3 \\
6 \\
14 \\
2\end{array}$ & $\begin{array}{l}0 \\
0 \\
0 \\
0 \\
0 \\
0 \\
0 \\
0 \\
0 \\
0\end{array}$ & $\begin{array}{l}0 \\
0 \\
0 \\
0 \\
0 \\
0 \\
0 \\
0 \\
0 \\
0\end{array}$ \\
\hline $\begin{array}{l}\text { Ncd9:1† } \\
\text { Ncd9:2 } \\
\text { Ncd9:3 } \\
\text { Ncd9:4 } \\
\text { Ncd9:5 }\end{array}$ & $\begin{array}{r}10 \\
36 \\
18 \\
26 \\
6\end{array}$ & $\begin{array}{l}90 \\
52 \\
74 \\
60 \\
90\end{array}$ & $\begin{array}{r}0 \\
12 \\
6 \\
14 \\
0\end{array}$ & $\begin{array}{l}0 \\
0 \\
2 \\
0 \\
4\end{array}$ & $\begin{array}{l}0 \\
0 \\
0 \\
0 \\
0\end{array}$ \\
\hline Ncd10(9:3) $\ddagger$ & $14(36)$ & $65(162)$ & $17(43)$ & $3(7)$ & $1(2)$ \\
\hline
\end{tabular}

* A noncomplementing diploid colony resulting from the protoplast fusion, denoted Ncdl, was subcloned and plated for single colonies. Fifty colonies were then tested by replica plating to all necessary selective media, except for Ned 7 where 36 colonies were plated. One of the eleven Ncd colonies thus identified was denoted Ncd 2 and the procedure repeated another nine times.

† Each of the five $\mathrm{Ned}$ colonies isolated by subcloning $\mathrm{Ncd} 8$ was itself subcloned $(\mathrm{Ncd} 9: 1-5)$ and 50 colonies were analysed as described in Methods.

† The colony Ncd9:3 was again subcloned and 250 single colonies were analysed as described in Methods. The numbers in parentheses represent the actual number of colonies observed.

\section{Table 5. Plasmid transfer by protoplast fusion}

Donor and recipient cells were grown to $10^{8}$ c.f.u. $\mathrm{ml}^{-1}$ according to Dancer (1980). Protoplasts were concentrated 25 -fold in SMMP and $0.5 \mathrm{ml}$ of each were mixed; $1.5 \mathrm{ml} 40 \%$ (w/v) PEG was added and after $2 \mathrm{~min}$ the protoplasts were diluted and washed twice in SMMP. After $4 \mathrm{~h}$ incubation, the protoplasts were diluted and plated on DM3 medium with and without antibiotic: chloramphenicol (Cm), $10 \mu \mathrm{g} \mathrm{ml}^{-1}$; erythromycin (Em), $2 \mu \mathrm{g} \mathrm{ml}^{-1}$; streptomycin (Sm), $100 \mu \mathrm{g} \mathrm{ml}^{-1}$; or kanamycin $(\mathrm{Km})$, $25 \mu \mathrm{g} \mathrm{ml}^{-1}$. The frequency of plasmid transfer was calculated as the number of resistant colonies per regenerated protoplast.

\begin{tabular}{|c|c|c|c|c|}
\hline Donor & Recipient & $\begin{array}{l}\text { Counter selection } \\
\text { against donor }\end{array}$ & Selection & Frequency \\
\hline B. subtilis & B. megaterium & & & \\
\hline $\begin{array}{l}\text { BR151/pCM194 } \\
\text { B. subtilis }\end{array}$ & $\begin{array}{l}\text { PV104 } \\
\text { B. megaterium }\end{array}$ & $\mathrm{Em}^{\mathrm{s}}$ & $\mathrm{Cm}^{\mathrm{R}}$ & $8.0 \times 10^{-9}$ \\
\hline $\begin{array}{l}\mathrm{BR} 151 / \mathrm{pUB} 110 \\
\text { B. megaterium }\end{array}$ & $\begin{array}{l}\text { JV78 } \\
\text { B. subtilis }\end{array}$ & $\mathrm{Sm}^{\mathbf{s}}$ & $\mathrm{K} \mathrm{m}^{\mathrm{R}}$ & $6.7 \times 10^{-6}$ \\
\hline PV170/pCM194 & BR151/pUB110 & $\mathrm{Km}^{\mathrm{S}}$ & $\mathrm{Cm}^{\mathrm{R}}$ & $7.6 \times 10^{-6}$ \\
\hline $\begin{array}{l}\text { B. megaterium } \\
\text { PV170/pCM194 } \\
\text { B. megaterium }\end{array}$ & $\begin{array}{l}\text { B. megaterium } \\
\text { JV26 } \\
\text { B. megaterium }\end{array}$ & $\mathrm{Sm}^{\mathrm{S}}$ & $\mathrm{Cm}^{\mathrm{R}}$ & $2.2 \times 10^{-5}$ \\
\hline PV170/pCM194 & JV78 & $\mathrm{Sm}^{\mathbf{S}}$ & $\mathrm{Cm}^{\mathrm{R}}$ & $\begin{array}{l}3.8 \times 10^{-6} \\
1.8 \times 10^{-5}\end{array}$ \\
\hline
\end{tabular}

\section{DISCUSSION}

Optimum conditions were established for production and regeneration of protoplasts of $B$. megaterium QM B1551 using a non-selective, simple regeneration medium. Some of the early variations observed in fusion recombinants in $B$. subtilis and $B$. megaterium had been attributed to variations in regeneration and the media used (Schaeffer et al., 1976; Fodor \& Alföldi, 1976). While consistent regeneration rates could be obtained by our methods, variability in recombination frequencies was still observed; this variability was thought not to be caused by variations in the regeneration rate or type of medium used. Gabor \& Hotchkiss (1982) controlled 
variation somewhat by freezing cells just before protoplasting, suggesting, as did Fodor \& Alföldi (1979), that growth of the cells and their physiological state before formation of protoplasts may influence the recombination rates. However, a more important factor may be the persistence of segregating complementing and noncomplementing diploids within the population. A previous attempt to detect Ncd colonies in isolated clones of $B$. megaterium (Fodor et al., 1983) was unsuccessful. Our experimental design could not have detected complementing diploids, but our observed frequency of Ncd colonies $(1-4 \%)$ is similar to the frequencies observed by Hotchkiss \& Gabor (1980) in B. subtilis (1-10\%). The segregation patterns of the Ncd colonies reported here also followed very closely those reported by Hotchkiss \& Gabor (1980); that is, the initial ratio of Ncd:parental-1:parental-2 was $1: 2: 2$, with double recombinants emerging after several subclonings. The similarity of the segregation patterns in the two species would suggest that several complementing diploids might also be present in the population following fusion in $B$. megaterium. By using a $s p o A$ mutation as an indicator, Sanchez-Rivas (1982) observed that as many as $50 \%$ of the prototrophic $B$. subtilis selected on minimal regeneration medium were complementing diploids. In addition, Bohin et al. (1982) have shown that the unexpressed chromosome in $B$. subtilis Ncd colonies can become biologically active in transformation if the DNA is first treated with protease. This phenomenon could not be tested in B. megaterium since chromosomal transformation is not presently possible.

We have shown that transfer of several plasmids between bacilli at frequencies of $10^{-5}-10^{-6}$ per regenerated protoplast is possible by protoplast fusion. These data corroborate the observations of Dancer (1980), who transferred plasmid pC221 by fusion among $B$. megaterium $\mathrm{KM}, B$. licheniformis, $B$. polymyxa and $B$. subtilis at frequencies of $1.3 \times 10^{-5}$ to $7.0 \times 10^{-6}$ per regenerated protoplast. Our results revealed no significant difference in frequency whether the transfer was inter- or intraspecific, suggesting that restriction of plasmid DNA did not occur between $B$. subtilis BR151 and B. megaterium QM B1551. All attempts to transfer a plasmid from Staphylococcus aureus to $B$. megaterium failed, however. Several $S$. aureus plasmids have been shown to replicate and to be expressed in our strain (Kieselburg et al., 1984), but the transfer has always been from a $B$. subtilis host. The failure to transfer plasmid pI 258 could be due to several factors, including restriction of foreign DNA, incompatibility with one of the seven resident plasmids in strain QM B1551, or lack of recognition by QM B1551 of the replication origin of this particular plasmid.

Although plasmids can be transferred successfully, genetic mapping cannot be done by analysis of the products of protoplast fusion in $B$. megaterium using the current methods. The data presented here and those of other Bacillus researchers are in sharp contrast to the successful use of fusion analysis in Streptomyces and Staphylococcus. Perhaps some property associated with Bacillus spore formation is involved, but this has so far not been determined. Genetic analysis of fusion recombinants in other Bacillus species has not been reported to our knowledge. Dancer \& Mandelstam (1981) demonstrated complementation of specific spo genes by fusion, taking advantage of conditions unique to sporulation. Whether their method can be modified to test other markers such as auxotrophic requirements remains to be tested.

The data presented here suggest that caution should be used in interpreting all fusion results and that great care should be taken to verify that cells resulting from fusions are haploid, still contain all expected genetic markers, and are stable.

The authors wish to thank Dr J. C. Vary for the generous sharing of auxotrophic strains of B. megaterium, and Dr Paul Lovett and Dr Peter Pattee for contributing strains of $B$. subtilis and $S$. aureus, respectively, carrying plasmids. This work was supported in part by grant PCM 8208323 from the National Science Foundation and subgrant 07176 awarded by the Biomedical Research Support Grant Program, Division of Research Resources, National Institutes of Health.

\section{REFERENCES}

BALTZ, R. H. (1978). Genetic recombination in Streptomyces fradiae by protoplast fusion and cell regeneration. Journal of General Microbiology 107 , 93-102.
Birnboim, H. C. \& Doly, J. (1979). A rapid alkaline extraction procedure for screening recombinant plasmid DNA. Nucleic Acids Research 7, 1513-1523.

Bohin, J. P., Khalifa, K. B., Guillen, N., 
Schaeffer, P. \& Hirschbein, L. (1982). Phenotypic expression in vivo and transforming activity in vitro: two related functions of folded bacterial chromosomes. Molecular and General Genetics 185, 65-68.

Callahan, J. P., Crawford, I. P., Hess, G. F. \& VARY, P.S. (1983). Cotransductional mapping of the trp-his region of Bacillus megaterium. Journal of Bacteriology 154, 1455-1458.

Chang, S. \& Cohen, S. N. (1979). High frequency transformation of Bacillus subtilis protoplasts by plasmid DNA. Molecular and General Genetics 168, $111-115$.

DANCER, B. N. (1980). Transfer of plasmids among bacilli. Journal of General Microbiology 121, 263-266.

Dancer, B. N. \& Mandelstam, J. (1981). Complementation of sporulation mutants in fused protoplasts of Bacillus subtilis. Journal of General Microbiology 123, 17-26.

FODOR, K. \& ALFöLDI, L. (1976). Fusion of protoplasts of Bacillus megaterium. Proceedings of the National Academy of Sciences of the United States of America 73, 2147-2150.

FoDOR, K. \& ALFöLdI, L. (1979). Polyethylene-glycol induced fusion of bacterial protoplasts. Molecular and General Genetics 168, 55-59.

Fodor, K., Hadlaczky, G. \& Alföldi, L. (1975). Reversion of Bacillus megaterium protoplasts to the bacillary form. Journal of Bacteriology 121, 390-391.

FodOR, K., LIPPAI-CSANADY, L. \& AlFöldi, L. (1983). A search for biparentals in Bacillus megaterium. Experientia (Supplementum) 45, 328-329.

Frehel, C., Lheritier, A., Sanchez-Rivas, C. \& SCHAEFFER, P. (1979). Electron microscopic study of Bacillus subtilis protoplast fusion. Journal of Bacteriology 137, 1354-1361.

GaboR, M. H. \& Hotchkiss, R. D. (1979). Parameters governing bacterial regeneration and genetic recombination after fusion of Bacillus subtilis protoplasts. Journal of Bacteriology 137, 1346-1353.

GaBOR, M. H. \& Hotchkiss, R. D. (1982). Analysis of randomly picked genetic recombinants from Bacillus subtilis protoplast fusion. In Genetic Exchange: $a$ Celebration and a New Generation, pp. 283-292. Edited by U. N. Streips, S. H. Goodgal, W. R. Guild \& G. A. Wilson. New York: Marcel Dekker.

Garbe, J. C., Hess, G. F., Franzen, M. A. \& Vary, P. S. (1984). Genetics of leucine biosynthesis in Bacillus megaterium QM B1551. Journal of Bacteriology 157, 454-459.

Guillen, N., Gabor, M. H., Hotchkiss, R. D. \& HiRSCHBEIN, L. (1982). Isolation and characterization of the nucleoid of non-complementing diploids from protoplast fusion in Bacillus subtilis. Molecular and General Genetics 185, 69-74.

Guillen, N., Sanchez-Rivas, C. \& Hirschbein, L. (1983). Absence of functional RNA encoded by a silent chromosome in noncomplementary diploids obtained from protoplast fusion in Bacillus subtilis. Molecular and General Genetics 191, 81-85.

HopwOOD, D. A. (1981). Genetic studies with bacterial protoplasts. Annual Review of Microbiology 35, 237272.

HoPwOOD, D. A. \& WRIGHT, H. M. (1978). Bacterial protoplast fusion: recombination in fused proto- plasts of Streptomyces coelicolor. Molecular and General Genetics 162, 307-317.

HopwOOD, D. A., WRIGHT, H. M. \& WARD, J. M. (1979). Applications of protoplasts in Streptomyces genetics. In Protoplasts - Applications in Microbial Genetics, pp. 5-11. Edited by J. F. Peberdy. Nottingham: Nottingham University Press.

Hotchkiss, R. D. \& GABOR, M. H. (1980). Biparental products of bacterial protoplast fusion showing unequal parental chromosome expression. Proceedings of the National Academy of Sciences of the United States of America 77, 3553-3557.

KieselburG, M. K., Weickert, M. \& VARY, P. S. (1984). Analysis of resident and transformant plasmids in Bacillus megaterium. Bio/Technology 2, 254259.

LAmmi, C. J. \& Vary, J. C. (1972). Deoxyribonucleic acid synthesis during outgrowth of Bacillus megaterium QM B1551 spores. In Spores V, pp. 277-282. Edited by H. O. Halvorson, R. S. Hanson \& L. L. Campbell. Washington, DC: American Society for Microbiology.

Luchansky, J. B. \& Pattee, P. A. (1984). Isolation of transposon Tn551 insertions near chromosomal markers of interest in Staphylococcus aureus. Journal of Bacteriology 159, 894-899.

SANCHEZ-RIvas, C. (1982). Direct selection of complementing diploids from PEG-induced fusion of Bacillus subtilis protoplasts. Molecular and General Genetics 185, 329-333.

Sanchez-Rivas, C. \& Garro, A. J. (1979). Bacterial fusion assayed by a prophage complementation test. Journal of Bacteriology 137, 1340-1345.

Sanchez-Rivas, C., Levi-Meyrueis, C., LazardMONIER, F. \& SCHAEFFER, P. (1982). Diploid state of phenotypically recombinant progeny arising after protoplast fusion in Bacillus subtilis. Molecular and General Genetics 188, 272-278.

SChaeffer, P., CAMI, B. \& Hotchiss, R. D. (1976). Fusion of bacterial protoplasts. Proceedings of the National Academy of Sciences of the United States of America 73, 215i-2155.

SHAY, L. \& VARY, J. C. (1978). Biochemical studies of glucose initiated germination in Bacillus megaterium. Biochimica et biophysica acta 538, 284-292.

Stahl, M. L. \& PatTeE, P. A. (1983). Computerassisted chromosomal mapping by protoplast fusion in Staphylococcus aureus. Journal of Bacteriology 154, 395-405.

VARY, J. C. (1972). Spore germination of Bacillus megaterium QM B1551 mutants. Journal of Bacteriology 112, 640-642.

VARY, P. S. (1979). Transduction in Bacillus megaterium. Biochemical and Biophysical Research Communications 88, 1119-1124.

Vary, P. S., Garbe, J. C., Franzen, M. \& Frampton, E. W. (1982). MPI3, a generalized transducing bacteriophage for Bacillus megaterium. Journal of Bacteriology 149, 1112-1119.

WYRICK, P. B. \& Rogers, H. J. (1973). Isolation and characterization of cell wall-defective variants of Bacillus subtilis and Bacillus licheniformis. Journal of Bacteriology 116, 456-465. 